\title{
Molecular Genetics of Charcot-Marie-Tooth Disease: From Genes to Genomes
}

\author{
H. Azzedine ${ }^{a} \quad$ J. Senderek ${ }^{b} \quad$ C. Rivolta ${ }^{a}$ R. Chrast $^{a}$ \\ ${ }^{a}$ Department of Medical Genetics, University of Lausanne, Lausanne, Switzerland; b Department of Neurology, \\ Friedrich-Baur-Institute, Ludwig Maximilian University, Munich, Germany
}

\section{Key Words}

Charcot-Marie-Tooth disease $\cdot$ Medical genetics •

Next-generation sequencing

\begin{abstract}
Charcot-Marie-Tooth disease (CMT) is a heterogeneous group of disorders of the peripheral nervous system, mainly characterized by distal muscle weakness and atrophy leading to motor handicap. With an estimated prevalence of 1 in 2,500, this condition is one of the most commonly inherited neurological disorders. Mutations in more than 30 genes affecting glial and/or neuronal functions have been associated with different forms of CMT leading to a substantial improvement in diagnostics of the disease and in the understanding of implicated pathophysiological mechanisms. However, recent data from systematic genetic screening performed in large cohorts of CMT patients indicated that molecular diagnosis could be established only in $\sim 50-70 \%$ of them, suggesting that additional genes are involved in this disease. In addition to providing an overview of genetic and functional data concerning various CMT forms, this review focuses on recent data generated through the use of highly parallel genetic technologies (SNP chips, sequence capture and next-generation DNA sequencing) in CMT families, and the current and future impact of these technologies on gene discovery and diagnostics of CMTs.

Copyright $\odot 2012$ S. Karger AG, Basel
\end{abstract}

\section{Charcot-Marie-Tooth Disease: Clinical and Genetic Heterogeneity}

Charcot-Marie-Tooth disease (CMT) is a clinically and genetically heterogeneous group of sensorimotor peripheral neuropathies and represents probably the most frequent cause of inherited pathologies affecting the nervous system [Skre, 1974]. The current classification of these disorders is based on clinical, electrophysiological, genetic and pathological criteria.

Physical examination of patients with CMT reveals symmetric distal amyotrophy in lower limbs and hands, steppage gait, foot deformities (pes cavus, pes planus, pes valgus), distal sensory loss in a stocking/glove distribution and decreased or absent deep tendon reflexes [Harding and Thomas, 1980a, b; Thomas and Harding, 1993]. Patients may have impaired proprioception with balance difficulty. Neuropathic pain may or may not be present [Siskind and Shy, 2011]. Spine deformities are not a constant sign of the disease but are more frequently associated with specific subtypes such as CMT4C [Azzedine et al., 2006]. Onset is classically within the first to second decade of life, with initial symptoms affecting the lower limbs but occasionally also the hands (e.g. GARS and GDAP1 mutations). However, there is a large spectrum of phenotypes, in terms of age of onset, disease progression and severity. Even among affected members of the same

\section{KARGER \\ Fax +4161306 1234 \\ E-Mail karger@karger.ch}

www.karger.com
(C) 2012 S. Karger AG, Basel

1661-8769/12/0035-0204\$38.00/0

Accessible online at:

www.karger.com/msy
Roman Chrast

Department of Medical Genetics

University of Lausanne

Rue de Bugnon 27, CH-1005 Lausanne (Switzerland)

E-Mail Roman.Chrast@unil.ch 
family carrying identical mutations, the phenotype may vary considerably. Other inherited peripheral neuropathies including hereditary motor neuropathies and hereditary sensory and autonomic neuropathies, which present a partially similar phenotype to CMT, are not covered by this review.

According to electrophysiological criteria including motor nerve conduction velocities (MNCV) and compound muscle action potential amplitudes, CMTs have been divided into 2 major subtypes; demyelinating (CMT1) and axonal (CMT2). In demyelinating forms, the $\mathrm{MNCV}$ in the upper extremities (median or ulnar nerve) are below $38 \mathrm{~m} / \mathrm{s}$. Conversely, patients with MNCV higher than $38 \mathrm{~m} / \mathrm{s}$ but with a decrease in compound muscle action potential amplitudes are considered to be affected by axonal CMT. A third, less-defined subtype of the disease called intermediate CMT is characterized by MNCV values between 38 and $45 \mathrm{~m} / \mathrm{s}$ (some authors report a larger interval: $25-35$ to $45 \mathrm{~m} / \mathrm{s}$ ) [Thomas and Calne, 1974; Bouche et al., 1983; Rossi et al., 1985; Verhoeven et al., 2001; Patzko and Shy, 2011].

Earlier studies have shown that approximately twothirds of CMTs are demyelinating and one-third is of primary axonal defect [Harding and Thomas, 1980a, b]. More recent studies in large cohorts of patients confirmed that most CMTs are demyelinating but lowered its prevalence to approximately half of all cases, while the prevalence of axonal forms was assessed to be less than one-third, i.e. 17.6-27.1\% [Foley et al., 2012; Murphy et al., 2012]. Moreover, the proportion of axonal or demyelinating CMT seems to depend on the geographical area, the structure of the population and the frequency of CMT in the general population. For example, in isolated European populations CMT1 and CMT2 are equally distributed, accounting for 48.2 and $49.4 \%$ of all cases, respectively [Nelis et al., 1996; Braathen et al., 2011; Foley et al., 2012].

The variability of the disease is also prominent at the genetic level. The pattern of inheritance can be autosomal dominant, autosomal recessive, or X-linked. To add to the complexity of the classification, more than 30 loci and genes have been identified in various forms of the disease (table 1, for additional information, see also: http://neuromuscular.wustl.edu/time/hmsn.html and www.molgen. ua.ac.be/CMTMutations/). Dominant forms are the most frequent ones in Western countries (up to 90\%). Recessive forms are conversely more prevalent $(30-50 \%$ of all CMT cases) in countries or populations displaying a high rate of consanguinity (Mediterranean basin, Middle East, European gypsies) while they account for only $\sim 4 \%$ of all cases in Europe [Dubourg et al., 2006; Patzko and Shy, 2011]. Importantly, depending on the nature and the position of the mutation, the same gene can be involved in demyelinating, axonal or intermediate forms, displaying autosomal dominant or recessive inheritance (tables 1 and 2).

Data from recent studies in relatively large cohorts of patients with CMT indicated that molecular diagnosis could be established in $60-70 \%$ of them [Saporta et al., 2011; Murphy et al., 2012]. The large majority of mutations ( $~ 90 \%$ ) were identified in PMP22, GJB1, MFN2, and $M P Z$, all genes involved in dominantly inherited CMTs. Concerning demyelinating CMT forms, molecular diagnosis was established in approximately $80 \%$ of patients and classical PMP22 duplications alone were responsible for $\sim 70 \%$ of all CMT1 cases. In the group of axonal CMT cases, molecular diagnosis was achieved in $\sim 25 \%$ of cases, the majority caused by mutations in MFN2 or GJB1.

\section{Molecular Pathology of CMTs}

Recent identification of a number of genes that were mutated in various forms of CMTs provided unprecedented insights into the biology of both Schwann cells and neurons. Although genes mutated in CMTs encode proteins involved in a relatively wide range of cellular functions, there are some emerging themes that can be identified.

Axonal forms of CMT (see table 2 for the complete list and references) affect both dorsal root ganglion sensory neurons and spinal motor neurons. Both of these neuronal cell types are extremely polarized, axons extending up to $1 \mathrm{~m}$ away from their soma to sensory receptors in muscle or skin and to neuromuscular junctions with skeletal muscles [Gentil and Cooper, 2012]. Since the majority of neuronal proteins are synthesized in the cell body, this particular cellular architecture requires intensive transport of proteins between the soma and the axonal extremity. Accordingly, mutations affecting DYNC1H1, which encodes the cytoplasmic dynein heavy chain 1 protein, a critical subunit of dynein1 responsible for axonal retrograde transport, lead to CMT. In addition, NEFL (encoding neurofilament protein) and LMNA (encoding lamin A/C) are both involved in neurofilament homeostasis, which, if disrupted, will affect axonal transport. HSPB1 and HSPB8 (small heat shock proteins acting as ATP-independent chaperones in protein folding) also play a role in the architecture of the cytoskeleton. Among the most dynamic organelles functionally dependent on proper axonal transport are mitochondria. Mutations in 
Table 1. Genetic classification of CMT

\begin{tabular}{|c|c|c|c|c|c|c|c|c|c|}
\hline \multirow[t]{2}{*}{ Inheritance } & \multicolumn{3}{|l|}{ Demyelinating forms } & \multicolumn{3}{|c|}{ Intermediate forms } & \multicolumn{3}{|l|}{ Axonal forms } \\
\hline & form & gene & OMIM & form & gene & OMIM & form & gene & OMIM \\
\hline \multirow[t]{14}{*}{ Autosomal dominant } & CMT1A/CMT1E & PMP22 & 601097 & DI-CMTA & $?$ & & CMT2A1/2 & MFN2/KIF1B & $608507 / 605995$ \\
\hline & CMT1B & $M P Z$ & 159440 & DI-CMTB & DNM2 & 602378 & CMT2B & $R A B 7$ & 602298 \\
\hline & CMT1C & LITAF & 603795 & DI-CMTC & YARS & 603623 & CMT2C & TRPV4 & 605427 \\
\hline & CMT1D & EGR2 & 129010 & DI-CMTD & $M P Z$ & 159440 & CMT2D & GARS & 600287 \\
\hline & CMT1F & $N E F L$ & 162280 & DI-CMTE & INF2 & 610982 & CMT2E & $N E F L$ & 162280 \\
\hline & & & & Slow SNV & ARHGEF10 & 608136 & CMT2F & HSP27 (HSPB1) & 602195 \\
\hline & & & & & & & CMT2G & $?$ & \\
\hline & & & & & & & CMT2I/2J & $M P Z$ & 159440 \\
\hline & & & & & & & СMT2K & GDAP1 & 606598 \\
\hline & & & & & & & CMT2L & HSP22 (HSPB8) & 608014 \\
\hline & & & & & & & CMT2M & DNM2 & 602378 \\
\hline & & & & & & & CMT2N & AARS & 601065 \\
\hline & & & & & & & СMT2O & DYNC1H1 & 600112 \\
\hline & & & & & & & СМТ2P & LRSAM1 & 610933 \\
\hline \multirow[t]{10}{*}{ Autosomal recessive } & CMT4A & GDAP1 & 606598 & RI-CMTA & GDAP1 & 606598 & ARCMT2A2 & MFN2 & 608507 \\
\hline & CMT4B1 & MTMR2 & 603557 & & & & CMT2B1 & LMNA & 150330 \\
\hline & CMT4B2 & MTMR13 (SBF2) & 607697 & & & & СMT2B2 & MED25 & 610197 \\
\hline & CMT4C & SH3TC2 & 608206 & & & & СMT2H & GDAP1 & 606598 \\
\hline & CMT4D (HMSNL) & $N D R G 1$ & 605262 & & & & СMT2P & LRSAM1 & 610933 \\
\hline & CMT4E & $E G R 2 / M P Z$ & $129010 / 159440$ & & & & & & \\
\hline & CMT4F & $P R X$ & 605725 & & & & & & \\
\hline & CMT4G (HMSNR) & $H K 1$ & & & & & & & \\
\hline & CMT4H & FGD4 & 611104 & & & & & & \\
\hline & CMT4J & FIG4 & 609390 & & & & & & \\
\hline X-linked dominant & & & & CMTX1 & GJB1 & 304040 & & & \\
\hline \multirow[t]{4}{*}{ X-linked recessive } & & & & CMTX2 & $?$ & & & & \\
\hline & & & & СMTX3 & $?$ & & & & \\
\hline & & & & CMTX4 & $?$ & & & & \\
\hline & & & & CMTX5 & PRPS1 & 311850 & & & \\
\hline
\end{tabular}

Genes KARS [McLaughlin et al., 2010] and CTDP1 [Varon et al., 2003] were not considered because they are associated with syndromic conditions for which peripheral neuropathy represents only a part of the pathology. ?= Disease gene is unknown.

2 different genes implicated in mitochondrial functions (MFN2 and GDAP1) lead to CMT. MFN2 interferes with mitochondrial axonal transport by interacting with the adaptor Miro/Milton complex, by which kinesin attaches mitochondria to microtubules. GDAP1 is a mitochondrial fission factor and is probably directly involved in the adaption of the number and size of mitochondria to the requirements of the cell. In addition, mutations in genes involved in protein synthesis and turnover (GARS, AARS, LRSAM1), endocytosis (RAB7, DNM2), calcium homeostasis (TRPV4), myelin assembly (MPZ) and gene expression regulation (MED25) are also leading to the axonal forms of CMT.

Large axons (with a diameter larger than $1 \mu \mathrm{m}$ ) are wrapped by a myelin sheath, which is a specialized cell membrane with a high lipid-to-protein ratio (lipids ac- count for at least $70 \%$ of the dry weight of myelin membranes [Chrast et al., 2011]). The presence of myelin around an axonal segment plays a role as an insulator (by increasing axonal resistance) and participates in the mechanisms leading to the clustering of axonal ion channels at nodes of Ranvier [Barres, 2008]. Myelinating Schwann cells therefore play a critical role in both the architecture and electrical properties of axons, allowing for a substantial increase (up to $100 \times$ ) in nerve conduction velocity while reducing axonal energy consumption [Hartline and Colman, 2007]. The importance of the appropriate assembly of the myelin membrane is highlighted by the fact that mutations in PMP22, MPZ and PRX, which all participate in the assembly of myelin, lead to CMT (table 2). The observation that changes in myelin protein gene dosage lead to CMT [Suter and Scherer, 2003; 


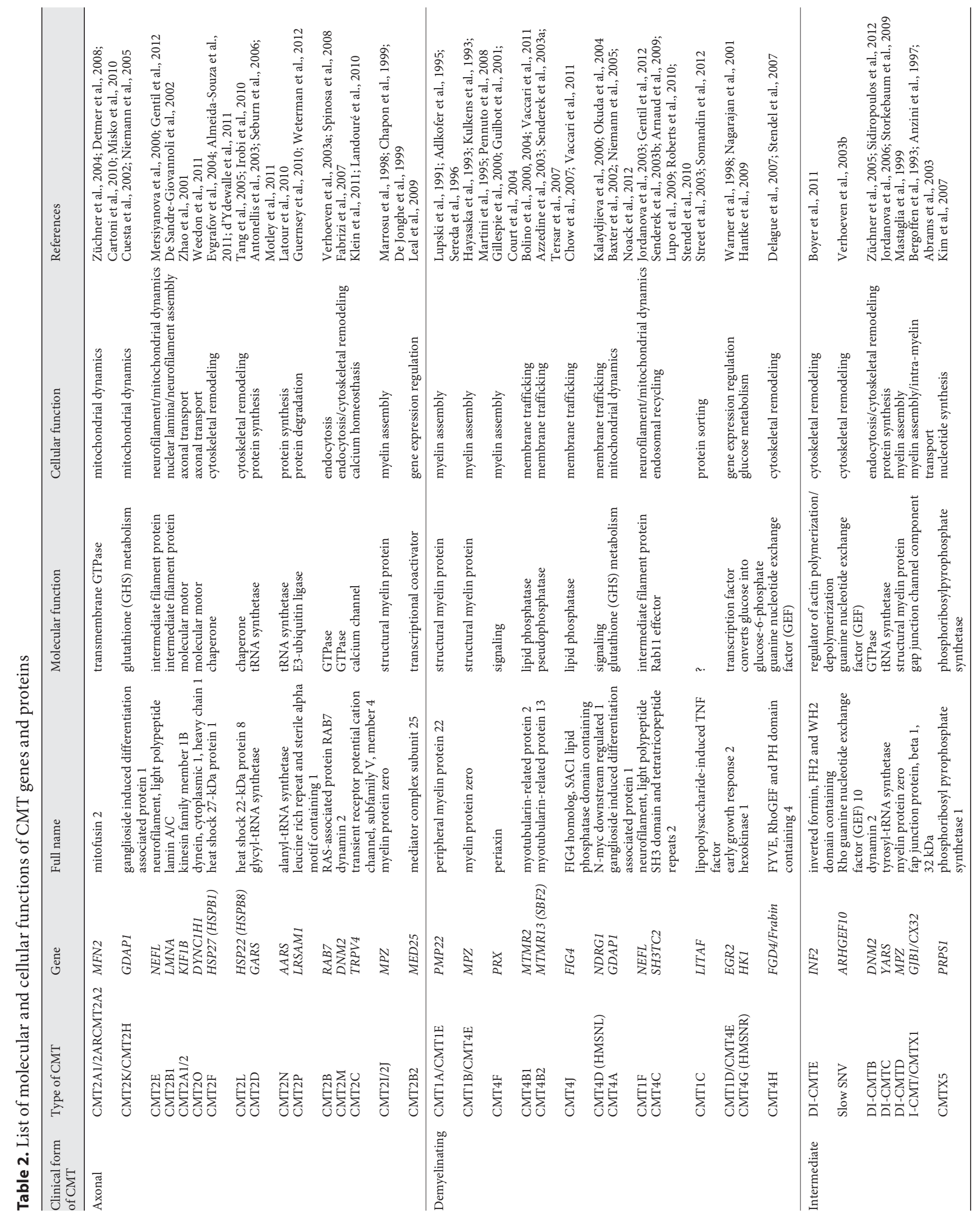


Maeda et al., 2012] is in agreement with the evidence that mutations in EGR2, a transcription factor that regulates myelin gene expression, also lead to a CMT phenotype. The estimated 6,500-fold increase in membrane surface occurring during myelination [Webster, 1971] and the highly polarized structure of Schwann cells suggest that membrane assembly, transport and maintenance are critical for proper Schwann cell function. The identification of mutations in MTMR2, MTMR13/SBF2, FIG4 and $N D R G 1$ genes (encoding proteins involved in membrane trafficking), in SH3TC2 (involved in endosomal recycling), in LITAF (involved in protein sorting) and in FGD4 (involved in cytoskeletal remodeling) supports this hypothesis and provides molecular insight into the various mechanisms involved in myelin membrane homeostasis.

Intermediate forms of CMT are expected to affect both glial and neuronal functions and highlight the close relationship between these 2 cell types. Mutations affecting genes encoding proteins involved in cytoskeletal remodeling (INF2 and DNM2), protein synthesis (YARS), myelin assembly (MPZ and GJB1) and nucleotide synthesis (PRPS1) lead to defects in Schwann cells and in axons.

The diversity of cellular and molecular functions of proteins that are associated with different forms of CMTs demonstrates that the identification of disease genes is a crucial step to obtain insights into both the pathophysiology of the disease and the biology of the peripheral nervous system. In terms of future gene identification efforts, the plethora of genes and gene products involved in CMTs (table 2) precludes simple predictions of additional CMT genes based solely on functional data. This aspect is further highlighted by the ubiquitous expression/function of many CMT genes identified so far (e.g. HSP27, HSP22, GARS, AARS, YARS, MTMR2, MTMR13/SBF2). Therefore, while data obtained through characterization of various CMT forms have generated a list of possible candidate pathways that may be selectively compromised in patients, one cannot exclude that other biological structures or biochemical reactions can be important in the molecular pathology of CMT.

\section{From Positional Cloning to Highly Parallel Genetic Technologies}

The majority of CMT genes have been identified by positional cloning, usually involving large families with multiple affected individuals to allow fine-mapping of the culprit mutation to a small region containing only few genes. In more recent times, gene hunting in CMTs (and other heterogeneous conditions) has been forced to adapt to less favorable conditions, classically represented by patients from small families yielding extended or even several regions of potential linkage. Scientists have therefore become more inventive, designing or integrating various techniques to overcome technical limitations. For example, research combining systematic screens with linkage results (e.g. blind mutational screenings of all genes present in a given linkage region) have allowed the discovery of mutations in genes that a priori were not considered as prime candidates (e.g. [Chakarova et al., 2007]). As mentioned above, strategies to prioritize candidate genes based on gene function (if known) and on similarity with or functional relation to genes involved in the same disease [Dryja, 1990, 1997] may not always be successful as structurally and functionally diverse gene products might cause the same or a similar phenotype. Another attractive strategy is to characterize the expression profile of candidate genes in the organ or tissue targeted by the disease. However, for hereditary neuropathies, this approach has been hampered so far by the scarcity of transcriptional data from the affected tissues, i.e. spinal cord and dorsal root ganglion neurons or Schwann cells. Recently, with the availability of high throughput transcriptional analysis techniques, we and others have generated large-scale expression data characterizing peripheral nerve development, degeneration and regeneration, which are now available for gene prioritization [Verheijen et al., 2003; Giambonini-Brugnoli et al., 2005; Verdier et al., 2012].

Regardless of the technique used to pre-select possible culprit sequences, detection of mutations has relied so far on the use of mid- to large-scale systems, i.e. Sanger sequencing [Sanger and Coulson, 1975], sometimes preceded by screening techniques such as single-strand conformation polymorphisms, denaturing high performance liquid chromatography or denaturing gradient gel electrophoresis. More recently, the discovery and the recent commercialization of next-generation sequencing (NGS) instruments have represented a real technological revolution in the field of molecular genetics.

In NGS-driven genomic and exomic approaches, the bulk of the analytical procedures consists in data filtering, since comprehensive sequencing of the human genome (or of its coding sequences) obviously generates much more information than what is required for the identification of the cause of a monogenic disease. In the context of single-gene hunting, only 1 or 2 of the $\sim 4$ million variants detected genome-wide (or $\sim 20,000$ for a typical exome) represent the 'signal', to be distinguished 
from the overwhelming noise represented by all other DNA changes.

For recessive Mendelian diseases, one of the most successful approaches for noise reduction is filtering for regions of the genome for which patients carry identical (homozygous or autozygous) alleles inherited from a common ancestor of both parents. In autosomal recessive CMT this is particularly valuable, as in geographic regions and communities with a high prevalence of consanguineous marriages (e.g. Arab countries, Turkey, Iran, Pakistan, Roma populations) autosomal recessive inheritance accounts for $30-50 \%$ of all CMT cases [Patzko and Shy, 2011]. Detection of autozygosity is usually performed by using polymorphic markers (commonly SNPs) and the identification of DNA stretches for which homozygosity of alleles is observed over several kilobases. Using whole-genome SNP homozygosity mapping and subsequent DNA sequencing, Fischer et al. [2012] were able to provide molecular diagnosis to 15 (63\%) out of 24 index cases with sporadic or autosomal recessive CMT. Information on SNPs can be obtained prior to exome or genome sequencing, or directly extracted from the genome or exome information. The difference between these 2 approaches relies mostly on costs: in large families, microarray-based genotyping for several members followed by the analysis of a single exome/genome is (currently) cheaper, while in small families or in single cases direct sequencing is to be preferred. Another advantage of homozygosity mapping over classical linkage is that in principle even small families can be informative enough to lead to the successful identification of the disease gene.

An alternative strategy for gene hunting for autosomal recessive CMT makes use of compound heterozygosity observed in the offspring of non-consanguineous parents with children with a recessive disorder: in this scenario, sequencing data will be filtered for genes in which 2 nonpolymorphic variants (putative mutations) are simultaneously present. This process allows reducing the number of candidate genes by up to 3 orders of magnitude, compared to the genes containing only a single variant. Finally, selection of DNA changes that are shared among affected members of the same pedigree can further reduce the list of putative disease genes to the point only the true mutation is left.

In autosomal dominant or X-linked CMTs, noise reduction can be achieved by a similar pipeline, such as filtering for variants that are shared among multiple patients from the same families [Weedon et al., 2011].

\section{Highly Parallel Genetic Technologies and CMT: Recent Discoveries}

While still in its infancy, various highly parallel genetic technology approaches have already lead to a successful identification of the causative mutations in some families affected with peripheral neuropathies.

In their landmark study, Lupski et al. [2010] described the complete genome sequencing of an individual affected with CMT1 performed with the use of one of these sequencing platforms. Comparison of the proband's sequence with the human genome reference sequence led to identification of 1,165,204 intragenic SNPs of which 9,069 were non-redundant SNPs predicted to lead to non-synonymous codon changes. The authors then concentrated on 54 coding SNPs (out of 3,148 putative SNPs) present in 40 genes known to be involved in neuropathy-like conditions. Of these, two were located in the SH3TC2 gene (1 previously unreported missense mutation, p.Y169H, and 1 known disease-causing nonsense mutation, p.R954X) indicating compound heterozygous mutations in this gene as a cause of CMT1.

An exome sequencing approach was used by Weedon et al. [2011] to study a large, 4-generation family affected by CMT2, in which various mutations in genes commonly associated with CMT2 (MFN2, MPZ, NEFL and LMNA) had been previously excluded by Sanger sequencing. Whole-exome sequencing was performed in 3 affected individuals and, based on an assumed autosomal dominant model of inheritance, the authors concentrated on novel heterozygous variants. Out of 177, 192, and 199 missense, nonsense, frameshift or splice site variants present in individual patients, only 1 variant was shared by all 3 affected individuals. The detected missense change (c.917A $>$ G, p.H306R) in cytoplasmic dynein heavy chain 1 gene (DYNC1H1) affects a highly conserved residue within its homodimerization domain.

A similar approach was used by Landouré et al. [2012] to study a family with a CMT2C phenotype (axonal CMT with vocal cord paralysis). One affected individual was analyzed by exome sequencing leading to identification of a novel sequence variant (c.557G $>$ A, p.R186Q) in the transient receptor potential vanilloid 4 gene (TRPV4) that was already known to cause CMT2C. Sanger sequencing confirmed the segregation of the mutation with the phenotype in the family. In addition, authors confirmed the pathogenicity of this variant in a cellular system.

Montenegro et al. [2011] also used exome sequencing to study a family with an axonal or intermediate form of CMT. Sequencing was performed in 2 affected individu- 
als leading to the identification of 86 unique single-nucleotide variants in 82 genes and 146 insertions/deletions (66 in coding exons) segregating in both individuals. One of these variants (c.283G $>\mathrm{A}$, V95M) affected the previously identified CMT gene GJB1.

A recent study by Auer-Grumbach et al. [2011] described the successful use of a combination of linkage analysis and NGS to identify missense variants in fibulin-5 that lead to a dominant form of CMT1. A genetic linkage study was performed in 2 families leading to the identification of a critical region on chromosome 14q32. After the exclusion of a few candidate genes (CALM1, GALC, PTPN21, KCNK13), the critical region was captured using a custom sequence capture array (Roche NimbleGen) and sequenced (454 GS-FLX, Roche). Sequence analysis revealed 12 non-synonymous sequence variants, eleven of which were known SNPs. The only new variant that was identified was in the FBLN5 gene (c.1117 C>T, p.R373C). Two additional fibulin-5 variants (c.268 G>A; p.G90S and c.376 G>A; p.V126M) were identified in 6 additional CMT patients.

A very similar approach was used by Weterman et al. [2012] to identify a frameshift mutation in LRSAM1. The linkage analysis run on a large 3-generation family led to the identification of a $5-\mathrm{Mb}$ region on $9 \mathrm{q} 33 \mathrm{q} 34$ with a LOD score of 5.12. The authors then used a custom sequence capture array covering the identified linkage region, to enrich, by sequence capture, the DNA from 1 affected individual which was subsequently sequenced. Sequence analysis revealed 5 heterozygous changes compatible with an autosomal dominant mode of inheritance. Subsequent segregation analysis and bioinformatic analyses revealed that the p.Leu708Argfx 28 frameshift mutation in LRSAM1 is underlying this dominant type of CMT.

\section{NGS and CMT: Perspectives}

Data from recent studies in large cohorts of CMT patients indicated that molecular diagnosis could be established in $\sim 50-70 \%$ of them [Baets et al., 2011; Saporta et al., 2011]. These results strongly indicate that an important number of additional CMT genes remains to be discovered. As discussed above, NGS technologies have the potential to help in achieving this goal.

In addition to their potential as a gene discovery tool, NGS technologies should be considered also as a diagnostic screening method. This is especially true in cases of CMT with substantial locus heterogeneity and/or where multiple large genes, making conventional screening of each patient time- and money-consuming, are implicated. Recent work by Choi et al. [2012] has already demonstrated the successful use of exome sequencing as a molecular diagnostic tool in CMT. In this study, 25 CMT patients who were negative for mutations in major CMT genes were analyzed by exome sequencing, leading to the identification of mutations in $32 \%$ of them. While this detection rate is relatively high, especially considering that these samples were pre-tested for the most common CMT genes, it also indicates the current limitations of this approach [Coppola and Geschwind, 2012].

In exome sequencing, the most prominent of these limitations is the selection of DNA to be analyzed. Since only exons and their flanking regions are interrogated, mutations in promoter areas, untranslated regions or any other non-exonic areas, as well as copy number variations, will be missed. Most important, in some instances capture kits allowing isolation of exonic regions are inefficient in isolating specific areas of the genome. As a consequence, the sequence coverage of CMT-related genes varies substantially (from 0 to more than 100 reads per base position) and some neuropathy-related genes including NEFL, WNK1 and SEPT9 cannot be analyzed at all [Montenegro et al., 2011]. However, this issue should be resolved, or at least substantially improved, with the commercialization of the next generation of exon capture kits, which should provide more comprehensive exome coverage.

The second and probably more challenging limitation is the issue of adequate exome data analysis. Each sequencing experiment leads to the identification of thousands of variants requiring subsequent filtering of previously identified benign variants. Various databases can be used to achieve this (1,000 Genomes Project: http:// www.1000genomes.org; dbSNP: http://www.ncbi.nlm.nih. gov/projects/SNP/, etc.). However, often even a very restrictive filtering step will lead to the identification of tens of candidates that are genetically and functionally potentially compatible with the disease. This highlights the importance of clinically well-characterized cohorts for data pooling and comparison or extended pedigrees allowing selection of meaningful variants through segregation analysis.

Although large-scale genetic approaches already provide useful tools to characterize patients affected by CMT disease, from the examples mentioned above it is clear that both NGS technologies and their analytical pipelines still need some improvement. The anticipated technological development leading to better sequence representa- 
tion, optimized filtering procedures and the establishment of a repository of coding variants identified in CMT patients will contribute to an improved success rate of NGS as a tool for both new gene discovery and diagnosis of CMT patients.

\section{Acknowledgements}

We would like to apologize to our colleagues whose work is not cited owing to space restrictions. This work was supported by Swiss National Science Foundation (to R.C. and C.R.) and by Gebert Rüf Stiftung (to C.R., R.C. and J.S.).

\section{References}

-Abrams CK, Freidin M, Bukauskas F, Dobrenis $\mathrm{K}$, Bargiello TA, et al: Pathogenesis of Xlinked Charcot-Marie-Tooth disease: differential effects of two mutations in connexin 32. J Neurosci 23:10548-10558 (2003).

-Adlkofer K, Martini R, Aguzzi A, Zielasek J, Toyka KV, Suter U: Hypermyelination and demyelinating peripheral neuropathy in Pmp22-deficient mice. Nat Genet 11:274280 (1995)

-Almeida-Souza L, Asselbergh B, d'Ydewalle C, Moonens K, Goethals S, et al: Small heatshock protein HSPB1 mutants stabilize microtubules in Charcot-Marie-Tooth neuropathy. J Neurosci 31:15320-15328 (2011).

-Antonellis A, Ellsworth RE, Sambuughin N, Puls I, Lee-Lin SQ, et al: Glycyl tRNA synthetase mutations in Charcot-Marie-Tooth disease type $2 \mathrm{D}$ and distal spinal muscular atrophy type V. Am J Hum Genet 72:12931299 (2003).

Anzini P, Neuberg DH, Schachner M, Nelles E, Willecke K, et al: Structural abnormalities and deficient maintenance of peripheral nerve myelin in mice lacking the gap junction protein connexin 32. J Neurosci 17: 4545-4551 (1997).

-Arnaud E, Zenker J, de Preux Charles AS, Stendel C, Roos A, et al: SH3TC2/KIAA1985 protein is required for proper myelination and the integrity of the node of Ranvier in the peripheral nervous system. Proc Natl Acad Sci USA 106:17528-17533 (2009).

-Auer-Grumbach M, Weger M, Fink-Puches R, Papić L, Fröhlich E, et al: Fibulin-5 mutations link inherited neuropathies, age-related macular degeneration and hyperelastic skin. Brain 134:1839-1852 (2011).

-Azzedine H, Bolino A, Taïeb T, Birouk N, Di Duca M, et al: Mutations in MTMR13, a new pseudophosphatase homologue of MTMR2 and $S b f 1$, in two families with an autosomal recessive demyelinating form of CharcotMarie-Tooth disease associated with earlyonset glaucoma. Am J Hum Genet 72:11411153 (2003).

-Azzedine H, Ravisé N, Verny C, Gabrëels-Festen A, Lammens M, et al: Spine deformities in Charcot-Marie-Tooth 4C caused by SH3TC2 gene mutations. Neurology 67:602-606 (2006).
Baets J, Deconinck T, De Vriendt E, Zimoń M, Yperzeele L, et al: Genetic spectrum of hereditary neuropathies with onset in the first year of life. Brain 134:2664-2676 (2011).

- Barres BA: The mystery and magic of glia: a perspective on their roles in health and disease. Neuron 60:430-440 (2008).

- Baxter RV, Ben Othmane K, Rochelle JM, Stajich JE, Hulette C, et al: Ganglioside-induced differentiation-associated protein-1 is mutant in Charcot-Marie-Tooth disease type 4A/8q21. Nat Genet 30:21-22 (2002).

Bergoffen J, Scherer SS, Wang S, Scott MO, Bone LJ, et al: Connexin mutations in X-linked Charcot-Marie-Tooth disease. Science 262: 2039-2042 (1993)

Bolino A, Muglia M, Conforti FL, LeGuern E, Salih MA, et al: Charcot-Marie-Tooth type $4 \mathrm{~B}$ is caused by mutations in the gene encoding myotubularin-related protein-2. Nat Genet 25:17-19 (2000).

Bolino A, Bolis A, Previtali SC, Dina G, Bussini $\mathrm{S}$, et al: Disruption of $M t m r 2$ produces CMT4B1-like neuropathy with myelin outfolding and impaired spermatogenesis. J Cell Biol 167:711-721 (2004).

- Bouche P, Gherardi R, Cathala HP, Lhermitte F, Castaigne P: Peroneal muscular atrophy. Part 1. Clinical and electrophysiological study. J Neurol Sci 61:389-399 (1983).

Boyer O, Nevo F, Plaisier E, Funalot B, Gribouval $\mathrm{O}$, et al: INF2 mutations in Charcot-MarieTooth disease with glomerulopathy. N Engl J Med 365:2377-2388 (2011).

Braathen GJ, Sand JC, Lobato A, Høyer H, Russell MB: Genetic epidemiology of CharcotMarie-Tooth in the general population. Eur J Neurol 18:39-48 (2011).

Cartoni R, Arnaud E, Médard JJ, Poirot O, Courvoisier DS, et al: Expression of mitofusin 2(R94Q) in a transgenic mouse leads to Charcot-Marie-Tooth neuropathy type 2A. Brain 133:1460-1469 (2010).

-Chakarova CF, Papaioannou MG, Khanna H, Lopez I, Waseem N, et al: Mutations in TOPORS cause autosomal dominant retinitis pigmentosa with perivascular retinal pigment epithelium atrophy. Am J Hum Genet 81:1098-1103 (2007).

Chapon F, Latour P, Diraison P, Schaeffer S, Vandenberghe A: Axonal phenotype of CharcotMarie-Tooth disease associated with a mutation in the myelin protein zero gene. J Neurol Neurosurg Psychiatry 66:779-782 (1999).
Choi BO, Koo SK, Park MH, Rhee H, Yang SJ, et al: Exome sequencing is an efficient tool for genetic screening of Charcot-Marie-Tooth disease. Hum Mutat (2012), E-pub ahead of print.

Chow CY, Zhang Y, Dowling JJ, Jin N, Adamska M, et al: Mutation of FIG4 causes neurodegeneration in the pale tremor mouse and patients with CMT4J. Nature 448:68-72 (2007).

Chrast R, Saher G, Nave KA, Verheijen MH: Lipid metabolism in myelinating glial cells: lessons from human inherited disorders and mouse models. J Lipid Res 52:419-434 (2011).

Coppola G, Geschwind DH: Genomic medicine enters the neurology clinic. Neurology 79: 112-114 (2012).

Court FA, Sherman DL, Pratt T, Garry EM, Ribchester RR, et al: Restricted growth of Schwann cells lacking Cajal bands slows conduction in myelinated nerves. Nature 431:191-195 (2004).

Cuesta A, Pedrola L, Sevilla T, García-Planells J, Chumillas MJ, et al: The gene encoding ganglioside-induced differentiation-associated protein 1 is mutated in axonal Charcot-Marie-Tooth type 4A disease. Nat Genet 30:2225 (2002).

d'Ydewalle C, Krishnan J, Chiheb DM, Van Damme P, Irobi J, et al: HDAC6 inhibitors reverse axonal loss in a mouse model of mutant HSPB1-induced Charcot-Marie-Tooth disease. Nat Med 17:968-974 (2011).

De Jonghe P, Timmerman V, Ceuterick C, Nelis E, De Vriendt E, et al: The Thr124Met mutation in the peripheral myelin protein zero (MPZ) gene is associated with a clinically distinct Charcot-Marie-Tooth phenotype. Brain 122 (Pt 2):281-290 (1999).

Delague V, Jacquier A, Hamadouche T, Poitelon Y, Baudot C, et al: Mutations in FGD4 encoding the Rho GDP/GTP exchange factor FRABIN cause autosomal recessive CharcotMarie-Tooth type 4H. Am J Hum Genet 81: 1-16 (2007).

De Sandre-Giovannoli A, Chaouch M, Kozlov S, Vallat JM, Tazir M, et al: Homozygous defects in $L M N A$, encoding lamin A/C nuclearenvelope proteins, cause autosomal recessive axonal neuropathy in human (Charcot-Marie-Tooth disorder type 2) and mouse. Am J Hum Genet 70:726-736 (2002). 
-Detmer SA, Vande Velde C, Cleveland DW, Chan DC: Hindlimb gait defects due to motor axon loss and reduced distal muscles in a transgenic mouse model of Charcot-MarieTooth type 2A. Hum Mol Genet 17:367-375 (2008).

Dryja TP: Human genetics. Deficiencies in sight with the candidate gene approach. Nature 347:614 (1990).

Dryja TP: Gene-based approach to human genephenotype correlations. Proc Natl Acad Sci USA 94:12117-12121 (1997).

-Dubourg O, Azzedine H, Verny C, Durosier G, Birouk N, et al: Autosomal-recessive forms of demyelinating Charcot-Marie-Tooth disease. Neuromolecular Med 8:75-86 (2006).

- Evgrafov OV, Mersiyanova I, Irobi J, Van Den Bosch L, Dierick I, et al: Mutant small heatshock protein 27 causes axonal CharcotMarie-Tooth disease and distal hereditary motor neuropathy. Nat Genet 36:602-606 (2004).

-Fabrizi GM, Ferrarini M, Cavallaro T, Cabrini I, Cerini $\mathrm{R}$, et al: Two novel mutations in dynamin-2 cause axonal Charcot-Marie-Tooth disease. Neurology 69:291-295 (2007).

- Fischer C, Trajanoski S, Papić L, Windpassinger C, Bernert G, et al: SNP array-based whole genome homozygosity mapping as the first step to a molecular diagnosis in patients with Charcot-Marie-Tooth disease. J Neurol 259: 515-523 (2012).

-Foley C, Schofield I, Eglon G, Bailey G, Chinnery PF, Horvath R: Charcot-Marie-Tooth disease in Northern England. J Neurol Neurosurg Psychiatry 83:572-573 (2012).

-Gentil BJ, Cooper L: Molecular basis of axonal dysfunction and traffic impairments in CMT. Brain Res Bull 88:444-453 (2012).

-Gentil BJ, Minotti S, Beange M, Baloh RH, Julien JP, Durham HD: Normal role of the low-molecular-weight neurofilament protein in mitochondrial dynamics and disruption in Charcot-Marie-Tooth disease. FASEB J 26: 1194-1203 (2012).

-Giambonini-Brugnoli G, Buchstaller J, Sommer L, Suter U, Mantei N: Distinct disease mechanisms in peripheral neuropathies due to altered peripheral myelin protein 22 gene dosage or a $P m p 22$ point mutation. Neurobiol Dis 18:656-668 (2005).

- Gillespie CS, Sherman DL, Fleetwood-Walker SM, Cottrell DF, Tait S, et al: Peripheral demyelination and neuropathic pain behavior in periaxin-deficient mice. Neuron 26:523531 (2000).

Guernsey DL, Jiang H, Bedard K, Evans SC, Ferguson $\mathrm{M}$, et al: Mutation in the gene encoding ubiquitin ligase LRSAM1 in patients with Charcot-Marie-Tooth disease. PLoS Genet 6pii:e1001081 (2010).

-Guilbot A, Williams A, Ravisé N, Verny C, Brice A, et al: A mutation in periaxin is responsible for CMT4F, an autosomal recessive form of Charcot-Marie-Tooth disease. Hum Mol Genet 10:415-421 (2001).
Hantke J, Chandler D, King R, Wanders RJ, Angelicheva $\mathrm{D}$, et al: A mutation in an alternative untranslated exon of hexokinase 1 associated with hereditary motor and sensory neuropathy - Russe (HMSNR). Eur J Hum Genet 17:1606-1614 (2009).

Harding AE, Thomas PK: The clinical features of hereditary motor and sensory neuropathy types I and II. Brain 103:259-280 (1980a).

Harding AE, Thomas PK: Genetic aspects of hereditary motor and sensory neuropathy (types I and II). J Med Genet 17:329-336 (1980b).

Hartline DK, Colman DR: Rapid conduction and the evolution of giant axons and myelinated fibers. Curr Biol 17:R29-35 (2007).

Hayasaka K, Himoro M, Sato W, Takada G, Uyemura K, et al: Charcot-Marie-Tooth neuropathy type $1 \mathrm{~B}$ is associated with mutations of the myelin P0 gene. Nat Genet 5:31-34 (1993).

-Irobi J, Almeida-Souza L, Asselbergh B, De Winter V, Goethals S, et al: Mutant HSPB8 causes motor neuron-specific neurite degeneration. Hum Mol Genet 19:3254-3265 (2010).

-Jordanova A, De Jonghe P, Boerkoel CF, Takashima H, De Vriendt E, et al: Mutations in the neurofilament light chain gene (NEFL) cause early onset severe Charcot-Marie-Tooth disease. Brain 126:590-597 (2003).

Jordanova A, Irobi J, Thomas FP, Van Dijck P, Meerschaert K, et al: Disrupted function and axonal distribution of mutant tyrosyl-tRNA synthetase in dominant intermediate Charcot-Marie-Tooth neuropathy. Nat Genet 38: 197-202 (2006).

Kalaydjieva L, Gresham D, Gooding R, Heather L, Baas F, et al: N-myc downstream-regulated gene 1 is mutated in hereditary motor and sensory neuropathy-Lom. Am J Hum Genet 67:47-58 (2000).

-Kim HJ, Sohn KM, Shy ME, Krajewski KM, Hwang M, et al: Mutations in PRPS1, which encodes the phosphoribosyl pyrophosphate synthetase enzyme critical for nucleotide biosynthesis, cause hereditary peripheral neuropathy with hearing loss and optic neuropathy (CMTX5). Am J Hum Genet 81:552558 (2007).

Klein CJ, Shi Y, Fecto F, Donaghy M, Nicholson $\mathrm{G}$, et al: TRPV4 mutations and cytotoxic hypercalcemia in axonal Charcot-Marie-Tooth neuropathies. Neurology 76:887-894 (2011).

Kulkens T, Bolhuis PA, Wolterman RA, Kemp S, te Nijenhuis S, et al: Deletion of the serine 34 codon from the major peripheral myelin protein $\mathrm{P} 0$ gene in Charcot-Marie-Tooth disease type 1B. Nat Genet 5:35-39 (1993).

Landouré G, Zdebik AA, Martinez TL, Burnett BG, Stanescu HC, et al: Mutations in TRPV4 cause Charcot-Marie-Tooth disease type 2C. Nat Genet 42:170-174 (2010).

Landouré G, Sullivan JM, Johnson JO, Munns $\mathrm{CH}$, Shi $\mathrm{Y}$, et al: Exome sequencing identifies a novel TRPV4 mutation in a CMT2C family. Neurology 79:192-194 (2012).
Latour P, Thauvin-Robinet C, Baudelet-Mery C, Soichot P, Cusin V, et al: A major determinant for binding and aminoacylation of tRNA(Ala) in cytoplasmic Alanyl-tRNA synthetase is mutated in dominant axonal Charcot-Marie-Tooth disease. Am J Hum Genet 86:77-82 (2010).

Leal A, Huehne K, Bauer F, Sticht H, Berger P, et al: Identification of the variant Ala335Val of MED25 as responsible for CMT2B2: molecular data, functional studies of the $\mathrm{SH} 3$ recognition motif and correlation between wildtype MED25 and PMP22 RNA levels in CMT1A animal models. Neurogenetics 10: 275-287 (2009).

- Lupo V, Galindo MI, Martínez-Rubio D, Sevilla T, Vílchez JJ, et al: Missense mutations in the SH3TC2 protein causing Charcot-MarieTooth disease type $4 \mathrm{C}$ affect its localization in the plasma membrane and endocytic pathway. Hum Mol Genet 18:4603-4614 (2009).

Lupski JR, de Oca-Luna RM, Slaugenhaupt S, Pentao L, Guzzetta V, et al: DNA duplication associated with Charcot-Marie-Tooth disease type 1A. Cell 66:219-232 (1991).

Lupski JR, Reid JG, Gonzaga-Jauregui C, Rio Deiros D, Chen DC, et al: Whole-genome sequencing in a patient with Charcot-MarieTooth neuropathy. N Engl J Med 362:11811191 (2010).

Maeda MH, Mitsui J, Soong BW, Takahashi Y, Ishiura $\mathrm{H}$, et al: Increased gene dosage of myelin protein zero causes Charcot-MarieTooth disease. Ann Neurol 71:84-92 (2012).

- Marrosu MG, Vaccargiu S, Marrosu G, Vannelli A, Cianchetti C, Muntoni F: Charcot-MarieTooth disease type 2 associated with mutation of the myelin protein zero gene. Neurology 50:1397-1401 (1998).

-Martini R, Zielasek J, Toyka KV, Giese KP, Schachner M: Protein zero (P0)-deficient mice show myelin degeneration in peripheral nerves characteristic of inherited human neuropathies. Nat Genet 11:281-286 (1995).

Mastaglia FL, Nowak KJ, Stell R, Phillips BA, Edmondston JE, et al: Novel mutation in the myelin protein zero gene in a family with intermediate hereditary motor and sensory neuropathy. J Neurol Neurosurg Psychiatry 67:174-179 (1999).

-McLaughlin HM, Sakaguchi R, Liu C, Igarashi T, Pehlivan D, et al: Compound heterozygosity for loss-of-function lysyl-tRNA synthetase mutations in a patient with peripheral neuropathy. Am J Hum Genet 87:560-566 (2010).

- Mersiyanova IV, Perepelov AV, Polyakov AV, Sitnikov VF, Dadali EL, et al: A new variant of Charcot-Marie-Tooth disease type 2 is probably the result of a mutation in the neurofilament-light gene. Am J Hum Genet 67:37-46 (2000). 
Misko A, Jiang S, Wegorzewska I, Milbrandt J, Baloh RH: Mitofusin 2 is necessary for transport of axonal mitochondria and interacts with the Miro/Milton complex. J Neurosci 30:4232-4240 (2010).

Montenegro G, Powell E, Huang J, Speziani F, Edwards YJ, et al: Exome sequencing allows for rapid gene identification in a CharcotMarie-Tooth family. Ann Neurol 69:464470 (2011).

Motley WW, Seburn KL, Nawaz MH, Miers KE, Cheng J, et al: Charcot-Marie-Tooth-linked mutant GARS is toxic to peripheral neurons independent of wild-type GARS levels. PLoS Genet 7:e1002399 (2011).

Murphy SM, Laura M, Fawcett K, Pandraud A, Liu YT, et al: Charcot-Marie-Tooth disease: frequency of genetic subtypes and guidelines for genetic testing. J Neurol Neurosurg Psychiatry 83:706-710 (2012).

- Nagarajan R, Svaren J, Le N, Araki T, Watson M, Milbrandt J: EGR2 mutations in inherited neuropathies dominant-negatively inhibit myelin gene expression. Neuron 30:355-368 (2001).

Nelis E, Van Broeckhoven C, De Jonghe P, Löfgren A, Vandenberghe A, et al: Estimation of the mutation frequencies in Charcot-MarieTooth disease type 1 and hereditary neuropathy with liability to pressure palsies: a European collaborative study. Eur J Hum Genet 4: 25-33 (1996).

- Niemann A, Ruegg M, La Padula V, Schenone A, Suter U: Ganglioside-induced differentiation associated protein 1 is a regulator of the mitochondrial network: new implications for Charcot-Marie-Tooth disease. J Cell Biol 170:1067-1078 (2005).

- Noack R, Frede S, Albrecht P, Henke N, Pfeiffer $A$, et al: Charcot-Marie-Tooth disease CMT4A: GDAP1 increases cellular glutathione and the mitochondrial membrane potential. Hum Mol Genet 21:150-162 (2012).

-Okuda T, Higashi Y, Kokame K, Tanaka C, Kondoh H, Miyata T: Ndrg1-deficient mice exhibit a progressive demyelinating disorder of peripheral nerves. Mol Cell Biol 24:39493956 (2004).

Patzko A, Shy ME: Update on Charcot-MarieTooth disease. Curr Neurol Neurosci Rep 11: 78-88 (2011).

- Pennuto M, Tinelli E, Malaguti M, Del Carro U, D'Antonio M, et al: Ablation of the UPR-mediator $\mathrm{CHOP}$ restores motor function and reduces demyelination in Charcot-MarieTooth 1B mice. Neuron 57:393-405 (2008).

- Roberts RC, Peden AA, Buss F, Bright NA, Latouche M, et al: Mistargeting of SH3TC2 away from the recycling endosome causes Charcot-Marie-Tooth disease type 4C. Hum Mol Genet 19:1009-1018 (2010).

Rossi A, Paradiso C, Cioni R, Rizzuto N, Guazzi G: Charcot-Marie-Tooth disease: study of a large kinship with an intermediate form. J Neurol 232:91-98 (1985).
Sanger F, Coulson AR: A rapid method for determining sequences in DNA by primed synthesis with DNA polymerase. J Mol Biol 94: 441-448 (1975).

- Saporta AS, Sottile SL, Miller LJ, Feely SM, Siskind CE, Shy ME: Charcot-Marie-Tooth disease subtypes and genetic testing strategies. Ann Neurol 69:22-33 (2011).

- Seburn KL, Nangle LA, Cox GA, Schimmel P, Burgess RW: An active dominant mutation of glycyl-tRNA synthetase causes neuropathy in a Charcot-Marie-Tooth 2D mouse model. Neuron 51:715-726 (2006).

Senderek J, Bergmann C, Weber S, Ketelsen UP, Schorle H, et al: Mutation of the SBF2 gene, encoding a novel member of the myotubularin family, in Charcot-Marie-Tooth neuropathy type $4 \mathrm{~B} 2 / 11 \mathrm{p} 15$. Hum Mol Genet 12 : 349-356 (2003a).

-Senderek J, Bergmann C, Stendel C, Kirfel J, Verpoorten N, et al: Mutations in a gene encoding a novel SH3/TPR domain protein cause autosomal recessive Charcot-Marie-Tooth type 4C neuropathy. Am J Hum Genet 73: 1106-1119 (2003b).

- Sereda M, Griffiths I, Pühlhofer A, Stewart H, Rossner MJ, et al: A transgenic rat model of Charcot-Marie-Tooth disease. Neuron 16: 1049-1060 (1996).

-Sidiropoulos PN, Miehe M, Bock T, Tinelli E, Oertli CI, et al: Dynamin 2 mutations in Charcot-Marie-Tooth neuropathy highlight the importance of clathrin-mediated endocytosis in myelination. Brain 135:1395-1411 (2012).

Siskind CE, Shy ME: Genetics of neuropathies. Semin Neurol 31:494-505 (2011).

Skre H: Genetic and clinical aspects of CharcotMarie-Tooth's disease. Clin Genet 6:98-118 (1974).

Somandin C, Gerber D, Pereira JA, Horn M, Suter U: LITAF (SIMPLE) regulates Wallerian degeneration after injury but is not essential for peripheral nerve development and maintenance: Implications for Charcot-MarieTooth disease. Glia 60:1518-1528 (2012).

Spinosa MR, Progida C, De Luca A, Colucci AM, Alifano P, Bucci C: Functional characterization of Rab7 mutant proteins associated with Charcot-Marie-Tooth type 2B disease. J Neurosci 28:1640-1648 (2008).

-Stendel C, Roos A, Deconinck T, Pereira J, Castagner F, et al: Peripheral nerve demyelination caused by a mutant Rho GTPase guanine nucleotide exchange factor, frabin/ FGD4. Am J Hum Genet 81:158-164 (2007).

-Stendel C, Roos A, Kleine H, Arnaud E, Ozçelik $\mathrm{M}$, et al: SH3TC2, a protein mutant in Charcot-Marie-Tooth neuropathy, links peripheral nerve myelination to endosomal recycling. Brain 133:2462-2474 (2010).

-Storkebaum E, Leitão-Gonçalves R, Godenschwege T, Nangle L, Mejia M, et al: Dominant mutations in the tyrosyl-tRNA synthetase gene recapitulate in Drosophila features of human Charcot-Marie-Tooth neuropathy. Proc Natl Acad Sci USA 106:11782-11787 (2009).
Street VA, Bennett CL, Goldy JD, Shirk AJ, Kleopa KA, et al: Mutation of a putative protein degradation gene LITAF/SIMPLE in Charcot-Marie-Tooth disease 1C. Neurology 60: 22-26 (2003).

Suter U, Scherer SS: Disease mechanisms in inherited neuropathies. Nat Rev Neurosci 4: 714-726 (2003).

Tang BS, Zhao GH, Luo W, Xia K, Cai F, et al: Small heat-shock protein 22 mutated in autosomal dominant Charcot-Marie-Tooth disease type 2L. Hum Genet 116:222-224 (2005).

Tersar K, Boentert M, Berger P, Bonneick S, Wessig C, et al: Mtmr13/Sbf2-deficient mice: an animal model for CMT4B2. Hum Mol Genet 16:2991-3001 (2007).

- Thomas PK, Calne DB: Motor nerve conduction velocity in peroneal muscular atrophy: evidence for genetic heterogeneity. J Neurol Neurosurg Psychiatry 37:68-75 (1974).

- Thomas PK, Harding AE: Inherited neuropathies: the interface between molecular genetics and pathology. Brain Pathol 3:129-133 (1993).

- Vaccari I, Dina G, Tronchere H, Kaufman E, Chicanne G, et al: Genetic interaction between MTMR2 and FIG4 phospholipid phosphatases involved in Charcot-MarieTooth neuropathies. PLoS Genet 7:e1002319 (2011).

-Varon R, Gooding R, Steglich C, Marns L, Tang $\mathrm{H}$, et al: Partial deficiency of the C-terminaldomain phosphatase of RNA polymerase II is associated with congenital cataracts facial dysmorphism neuropathy syndrome. Nat Genet 35:185-189 (2003).

- Verdier V, Csárdi G, de Preux-Charles AS, Médard JJ, Smit AB, et al: Aging of myelinating glial cells predominantly affects lipid metabolism and immune response pathways. Glia 60:751-760 (2012).

-Verheijen MH, Chrast R, Burrola P, Lemke G: Local regulation of fat metabolism in peripheral nerves. Genes Dev 17:2450-2464 (2003).

-Verhoeven K, Villanova M, Rossi A, Malandrini A, De Jonghe P, Timmerman V: Localization of the gene for the intermediate form of Charcot-Marie-Tooth to chromosome 10q24.1-q25.1. Am J Hum Genet 69:889-894 (2001).

Verhoeven K, De Jonghe P, Coen K, Verpoorten $\mathrm{N}$, Auer-Grumbach M, et al: Mutations in the small GTP-ase late endosomal protein RAB7 cause Charcot-Marie-Tooth type 2B neuropathy. Am J Hum Genet 72:722-727 (2003a).

Verhoeven K, De Jonghe P, Van de Putte T, Nelis E, Zwijsen A, et al: Slowed conduction and thin myelination of peripheral nerves associated with mutant rho Guanine-nucleotide exchange factor 10. Am J Hum Genet 73: 926-932 (2003b). 
-Warner LE, Mancias P, Butler IJ, McDonald CM, Keppen L, et al: Mutations in the early growth response 2 (EGR2) gene are associated with hereditary myelinopathies. Nat Genet 18:382-384 (1998).

-Webster HD: The geometry of peripheral myelin sheaths during their formation and growth in rat sciatic nerves. J Cell Biol 48:348-367 (1971).
Weedon MN, Hastings R, Caswell R, Xie W, Paszkiewicz K, et al: Exome sequencing identifies a DYNC1H1 mutation in a large pedigree with dominant axonal Charcot-MarieTooth disease. Am J Hum Genet 89:308-312 (2011).

Weterman MA, Sorrentino V, Kasher PR, Jakobs $\mathrm{ME}$, van Engelen BG, et al: A frameshift mutation in LRSAM1 is responsible for a dominant hereditary polyneuropathy. Hum Mol Genet 21:358-370 (2012).

Zhao C, Takita J, Tanaka Y, Setou M, Nakagawa $\mathrm{T}$, et al: Charcot-Marie-Tooth disease type $2 \mathrm{~A}$ caused by mutation in a microtubule motor KIF1Bbeta. Cell 105:587-597 (2001).
Züchner S, Mersiyanova IV, Muglia M, BissarTadmouri N, Rochelle J, et al: Mutations in the mitochondrial GTPase mitofusin 2 cause Charcot-Marie-Tooth neuropathy type 2A. Nat Genet 36:449-451 (2004).

Züchner S, Noureddine M, Kennerson M, Verhoeven $\mathrm{K}$, Claeys $\mathrm{K}$, et al: Mutations in the pleckstrin homology domain of dynamin 2 cause dominant intermediate Charcot-Marie-Tooth disease. Nat Genet 37:289-294 (2005). 